\title{
Influence of intraperitoneal administration of cerium oxide on blood parameters and lipid profile in mice (Mus musculus)
}

\author{
Samaher Sabri Hammid ${ }^{1}$ \& Sami Jeber Al-Maliky ${ }^{2}$ \\ ${ }^{1}$ Department of medical sciences college of nursing - university of Basrah-Iraq; \\ ${ }^{2}$ Prof. College of Education for pure sciences - university Basrah University-Iraq
}

\section{Abstract}

White laboratory mice Mus musculus L. strain BALB / C were used to study the effects cerium oxide on the hematological parameters and lipid profile values. Results showed a significant decrease $(\mathrm{p} \leq 0.05)$ in the RBCs' hemoglobin $\mathrm{Hb}$ 'and PCV' parameters as well as the presence of a significant in the mean erythrocyte MCV volume in the two doses (2.5'and .3.75) micro liters / $\mathrm{kg}$ ', while there was no significant difference in hemoglobin $(\mathrm{MCH})$ and the mean concentration of hemoglobin in red blood cells (MCHC) when compared with the control group, while the two doses did not differ significantly in PCV, Hb, RBCs, while the two doses differed significantly between them in MCV. there is significant difference in the level of triglycerides (TG, LDL) and HDL (compared with the control group) for both doses, and it was found that there was a significant difference between the low and high dose (2.'3.75) micro liters / $\mathrm{kg}$ in the HDL level. TG, LDL) compared with the control group at the probability level $(\mathrm{P} \leq 0.05)$, while there was no difference between the high and low dose in the level of cholesterol and (VLDL).

Key words: Cerium oxide, liver enzymes , Kidney ,rats

\section{Introduction}

The widespread interest in nanoparticles comes from the small particle size resulting in novel properties such as 'enhanced chemical interaction', optical behavior and large surface $(\mathbf{1}, \mathbf{2 , 3})$. It is already used in many applications including household products, equipment, food, medicine, optics, sun lotions, cosmetics, paints, textiles, electronics, and bioremediation production $(\mathbf{4 , 5})$.

The increasingly widespread use and interest shown by the industry about NPs and consequently on nanomaterials 'increased distribution resulting in increased public and occupational exposure' and thus raised questions about the potential impact of these new materials on the environment and human health (6). Cerium oxide is an example of nanoparticles which are the basis as additive sources of fuel to enhance combustion efficiency and clean the engine 'and reduce fuel consumption and emissions to the environment (7).

Cerium oxide nanoparticles (CNPs) that consist of cerium atoms bonded to oxygen atoms' have been used in commercial, industrial and biological applications (8. Consequently the present study carried out to investigate the effect of cerium oxide on blood and lipids profile parameters 


\section{Material and methods}

The current study was conducted on white laboratory mice Mus musculus L. strain BALB / C that was obtained from (Center for Drug Control - College of Science, DhiQar University). The mice were raised in the animal house of the Department of biology department - College of Education in Pure Sciences - University of Basra under Controlled conditions with a temperature of $20-25^{\circ} \mathrm{C}$ and a lighting cycle of 12 hours of light and 12 hours of darkness (AL-Malki, 2000). The mice were placed in plastic cages of standard sizes 30 X 12 X $11 \mathrm{~cm}$ manufactured by North Kint Plastic Kint.UK. . Sawdust was used as a bed and it was replaced weekly.

Malemice were divided,10-12 weeks old, with a weight of 20-25 grams for each test mice divided into three groups consisting of eight mice each as follows(1)The control group

Laboratory mice were injected with $1 \mathrm{ml}$ of Normal saline,(2) Treated group, were injected with $1 \mathrm{ml}$ of cerium oxide at a concentration of 2.51 of the raw material to 997.51 of the physiological solution. Equivalent to $0.05 \mathrm{mg} / 100$ body weight. The second group were injected with $1 \mathrm{ml}$ of cerium oxide at a concentration of 3.75 of the raw material to 996.251 of physiological solution, equivalent to $0.05 \mathrm{ml} / 100$ grams of body weight. Duration of the Injection period were 15 and 30 days, with one injection every two days, for 15,30 days.Effective Material is a substance of cerium oxide found in the form of a concentrated liquid solution in a package volume of 100 milliliters containing the active substance cerium oxide at a concentration of $20 \%$, produced by SIGMA (USA). Draw blood from the heart directly by the cardiac puncher using a $1 \mathrm{ml}$ disposable syringe, put the blood in tubes containing EDTA for blood parameters tests. As for the blood for the purposes of biochemical tests, the blood was placed in glass tubes free of anticoagulant. It contains a gelatinous substance tube and left for 10-15minutes to coagulate, then the tubes were placed in a Centrifuge for 10 minutes at $3500 \mathrm{rpm}$ in order to obtain an adequate amount of blood serum, then the serum was drawn from the coagulated blood and kept in special tubes with a at $-20^{\circ} \mathrm{C}$ until the biochemical tests are performed. Physiological parameters were measured using a hematology analyzer and spectrophotometer for lipids measurement. An analysis of variance one way using Statistical Package for Social Sciences (SPSS, V.11) was used.

\section{Results and discussion}

Table (1) showed the results of the effect of cerium oxide on the hematological parameters of male laboratory mice. Results showed a significant decrease at the probability level $(\mathrm{p} \leq 0.05)$ in the RBCs' hemoglobin $\mathrm{Hb}$ 'and PCV' as well as the presence of a significant decrease $(\mathrm{P} \leq 0.05)$ in the mean erythrocyte $\mathrm{MCV}$ volume in the two doses $(2.5,3.75)$ micro liters / $\mathrm{kg}$ 'while there was no significant difference in the rate of hemoglobin $(\mathrm{MCH})$ and the mean concentration of hemoglobin in red blood cells (MCHC) when compared with the control group, while the two doses did not differ significantly between them in the rate of $\mathrm{PCV}, \mathrm{Hb}, \mathrm{RBCs}$, while the two doses differed significantly between them in the rate of $\mathrm{MCV}$.our results showed agreement with(9) who revealed that diets supplemented with $\mathrm{CeO}$, particularly at $200 \mathrm{ppm}$ concentration, is capable of improving body weight gain, daily dry matter intake and feed conversion ratio in rabbits without any detrimental effect on the blood parameters indicating good health status of the animals. 
Table ( 1 ) The effect of cerium oxide on the mean of some blood parameters in male laboratory mice For fifteen days $(n=7)($ Mean $\pm S E)$.

\begin{tabular}{|c|c|c|c|c|c|c|}
\hline Parameters & $\begin{array}{c}\text { RBC } \\
\text { count } \\
\text { Cell/mlX } \\
10^{6} \\
\end{array}$ & Hb g/dL & PCV \% & MCV ft & MCH pg & $\underset{\%}{\text { MCHC }}$ \\
\hline $\begin{array}{l}\text { Control } 1 \mathrm{ml} \\
\text { saline }\end{array}$ & $\begin{array}{l}7.65 \pm \\
0.081\end{array}$ & $\begin{array}{l}13.457 \pm \\
0.287\end{array}$ & $\begin{array}{l}45.00 \pm \\
0.899\end{array}$ & $\begin{array}{l}61.285 \pm \\
1.215\end{array}$ & $\begin{array}{l}17.971 \pm \\
0.229\end{array}$ & $\begin{array}{l}30.328 \pm \\
0.379\end{array}$ \\
\hline $\begin{array}{l}\text { T11 ml }(2.5 \\
\text { uL/100g ) CeO }\end{array}$ & $\begin{array}{l}\mathrm{L} \\
4.842 \pm \\
0.404 \\
\end{array}$ & $\begin{array}{l}\mathrm{L} \\
6.921 \pm \\
0.393 \\
\end{array}$ & $\begin{array}{l}\mathrm{L} \\
23.771 \pm \\
1.678\end{array}$ & $\begin{array}{l}1 \\
50.5000 \pm \\
2.592 \\
\end{array}$ & $\begin{array}{l}16.571 \pm \\
0.666\end{array}$ & $\begin{array}{l}30.615 \pm \\
0.445\end{array}$ \\
\hline $\begin{array}{lr}\text { T2 ml } & 3.7 \\
(\mathrm{uL} / 100 \mathrm{~g} & \\
\mathrm{CeO} & \end{array}$ & $\begin{array}{l}\mathrm{L} \\
4.287 \pm \\
0.609\end{array}$ & $\begin{array}{l}\mathrm{L} \\
7.957 \pm \\
1.155\end{array}$ & $\begin{array}{l}\mathrm{L} \\
22.773 \pm \\
2.890\end{array}$ & $\begin{array}{l}\mathrm{L} \\
55.959 \pm \\
2.283 \\
\end{array}$ & $\begin{array}{l}18.128 \pm \\
0.671\end{array}$ & $\begin{array}{l}31.614 \pm \\
1.082\end{array}$ \\
\hline
\end{tabular}

*I different from control $\mathrm{p}<0.05$

A study by (10) demonstrated the effect of toxicity of cerium oxide nanoparticles on blood cells in male mice, where the mean total hematocrit and average red blood cell (RBC) count were observed in all experimental groups; but white blood cells (WBC) compared to the group Controls' only have linear increment

Table ( 2 ) The effect of cerium oxide on the mean of some blood parameters in male laboratory mice For thirty days $(n=7)($ Mean $\pm S E)$.

\begin{tabular}{|c|c|c|c|c|c|c|}
\hline Parameter & $\begin{array}{l}\text { RBC count } \\
\text { Cell/mlX10 }\end{array}$ & $\mathrm{Hb}$ g/dL & PCV \% & MCV ft & $\begin{array}{c}\text { MCH } \\
\text { pg }\end{array}$ & МСНС \% \\
\hline $\begin{array}{l}\text { Control } \\
1 \mathrm{ml} \text { saline }\end{array}$ & $\begin{array}{l}7.214 \pm \\
0.427\end{array}$ & $\begin{array}{l}13.385 \pm \\
0.318\end{array}$ & $45.142 \pm 0.769$ & $\begin{array}{l}59.214 \pm \\
0.634\end{array}$ & $\begin{array}{l}17.728 \pm \\
0.357\end{array}$ & $\begin{array}{l}30.214 \pm 0.2 \\
19\end{array}$ \\
\hline $\begin{array}{l}\text { T11 ml } \\
(2.5 \\
\text { uL/100g }) \\
\text { CeO }\end{array}$ & $\begin{array}{c}1 \\
4.400 \pm \\
0.691\end{array}$ & $\begin{array}{c}1 \\
5.714 \pm \\
0.449\end{array}$ & $\begin{array}{c}1 \\
20.071 \pm \\
0889\end{array}$ & $\begin{array}{c}1 \\
46.628 \pm \\
1.107\end{array}$ & $\begin{array}{c}1 \\
16.185 \pm \\
0.670\end{array}$ & $\begin{array}{c}1 \\
29.654 \\
\pm 0.312\end{array}$ \\
\hline $\begin{array}{l}\text { T2 ml } 3.7 \\
(\mathrm{uL} / 100 \mathrm{~g}) \\
\mathrm{CeO}\end{array}$ & $\begin{array}{c}1 \\
4.171 \pm \\
0.494\end{array}$ & $\begin{array}{c}1 \\
5.285 \pm \\
0.401\end{array}$ & $\begin{array}{c}1 \\
24.285 \pm \\
3.746\end{array}$ & $\begin{array}{c}1 \\
44.785 \pm \\
1.757\end{array}$ & $\begin{array}{c}1 \\
16.814 \pm \\
1.165\end{array}$ & $\begin{array}{c}1 \\
30.616 \\
\pm 1.084\end{array}$ \\
\hline
\end{tabular}

$*$ I different from control $\mathrm{p}<0.05$

Low $\mathrm{Hb}$ and PCV indicate presence of anemia ,(11)insure the founding of the recent study, hefound that treatedgroup showed normocytic normochromic anemia at the 7 th day and microcytic hypochromic anemia at the 15th day.

The results in Table ( 2 ) showed a significant decrease in the red blood cells (RBCs), the rate of hemoglobinemia $(\mathrm{Hb})$, the volume of compressed blood PCV, and the average red blood cell volume (MCV) in the two doses (2.5-3.75) micro liters / kg show a decrease'at a probability level (0.05) $\mathrm{P} \leq$ when compared with the control group, while the two doses did not show a significant difference in the rate of hemoglobin $\mathrm{MCH}$ and the mean hemoglobin concentration in the red blood cell MCHC when compared with the control 
group, but at the level of the two doses, exhibited significantly differ in RBCs, Hb, PCV, $\mathrm{MCV}, \mathrm{MCH}$ and $\mathrm{MCHC}$.

The findings of (12) exhibit that, although CNPs did not significantly perturb the native conformation of $\mathrm{Hb}$, they can stimulate some cellular adverse effects at high concentrations

The current study results showed a significant increase in the level of total cholesterol and HDL and LDL' for male laboratory mice injected with a high dose (3.75) micro liters / $\mathrm{kg}$ of cerium oxide at a probability level $(\mathrm{p} \leq 0.05)$ compared with the control group 'while there was no significant difference. In the level of triglycerides (TG) and VLDL) compared with the control group at the probability level $(\mathrm{P} \leq 0.05)$ for both doses, It was also found that there was a significant difference between the low and high dose (2.5-3.75) micro liters / $\mathrm{kg}$ in the LDL level compared with the control group at the level of $(\mathrm{P} \leq 0.05)$ 'while there was no difference between high and low dose in cholesterol and (LDL)'.

The results also showed that there was a significant difference between the low dose and the high dose compared with the control group 'in the level of HDL and the presence of a significant difference between the two doses when compared to them' as shown in the table ( 3)

Table (3) The effect of cerium oxide on lipid profile of male laboratory mice for fifteen days $(n=7)$ (Mean \pm standard error

\begin{tabular}{|l|c|c|c|c|c|}
\hline Rarameters & $\begin{array}{c}\text { Cholesterol } \\
\mathbf{m g} / \mathbf{d L}\end{array}$ & $\begin{array}{c}\text { TG g/dL } \\
\mathbf{m g} / \mathbf{d L}\end{array}$ & $\begin{array}{c}\text { HDL } \\
\mathbf{m g} / \mathbf{D l}\end{array}$ & $\begin{array}{c}\text { LDL } \\
\mathbf{m g} / \mathbf{d L}\end{array}$ & $\begin{array}{c}\text { VLDL } \\
\mathbf{~ m g / d L}\end{array}$ \\
\hline $\begin{array}{l}\text { Control 1ml } \\
\text { saline }\end{array}$ & $\begin{array}{l}117.476 \pm \\
1.674\end{array}$ & $\begin{array}{l}131.909 \pm \\
12.922\end{array}$ & $\begin{array}{l}77.585 \pm \\
958\end{array}$ & $\begin{array}{l}23.454 \pm \\
742\end{array}$ & $\begin{array}{l}26.381 \pm \\
2.584\end{array}$ \\
\hline T11 ml (2.5 & 1 & 1 & 1 & 1 & 1 \\
$\mathbf{u L / 1 0 0 g})$ & $133.397 \pm 1$ & $111.360 \pm 1$ & $87.260 \pm 1$ & $31.027 \pm 1$ & $22.271 \pm 1$ \\
CeO & 3.751 & 9.692 & 2.317 & 817 & 1.938 \\
\hline T2 ml 3.7 & 1 & 1 & 1 & 1 & 1 \\
$(\mathbf{u L} / \mathbf{1 0 0 g})$ & $137.783 \pm 1$ & $115.325 \pm 1$ & $93.541 \pm 1$ & $33.505 \pm 1$ & $23.065 \pm 1$ \\
CeO & 2.136 & 9.340 & 1.689 & 1.093 & 1.868 \\
\hline
\end{tabular}

$*$ I different from control $\mathrm{p}<0.05$

The results of the current study showed a significant increase in the level of total cholesterol and HDL 'LDL' for male laboratory mice injected with a high dose (3.75) micro liters / $\mathrm{kg}$ 'of cerium oxide at a probability level $(\mathrm{p} \leq 0.05)$ compared with the control group' while it was found that there is Significant difference in the level of triglycerides (TG, LDL) and HDL (compared with the control group) at the probability level $(\mathrm{P} \leq 0.05)$ for both doses, and it was found that there was a significant difference between the low and high dose (2.5'3.75) micro liters / $\mathrm{kg}$ in the HDL level. TG, LDL) compared with the control group at the probability level $(\mathrm{P} \leq 0.05)$, while there was no difference between the high and low dose in the level of cholesterol and (VLDL), as shown in the table. 
DOI : https://dx.doi.org/10.26808/rs.ph.i10v6.02

International Journal of Pharmaceutical Science and Health

Issue 10, Vol.6 (Nov.-Dec. 2020)

Available online on http://www.rspublication.com/ijphc/index.html

ISSN $2249-5738$

Table (4) The effect of cerium oxide on lipid profile of male laboratory mice for thirty days $(n=7)$ (rate \pm standard error)

\begin{tabular}{|l|c|c|c|c|c|}
\hline Rarameters & $\begin{array}{c}\text { Cholesterol } \\
\mathbf{m g} / \mathbf{d L}\end{array}$ & $\begin{array}{c}\text { TG g/dL } \\
\mathbf{m g} / \mathbf{d L}\end{array}$ & $\begin{array}{c}\text { HDL } \\
\mathbf{m g} / \mathbf{D l}\end{array}$ & $\begin{array}{c}\text { LDL } \\
\mathbf{m g} / \mathbf{d L}\end{array}$ & $\begin{array}{c}\text { VLDL } \\
\mathbf{m g} / \mathbf{d L}\end{array}$ \\
\hline $\begin{array}{l}\text { Control 1ml } \\
\text { saline }\end{array}$ & $\begin{array}{c}120.908 \pm \\
1.277\end{array}$ & $\begin{array}{c}134.001 \pm \\
0.792\end{array}$ & $\begin{array}{c}83.850 \pm \\
1.959\end{array}$ & $\begin{array}{c}23.781 \pm \\
0.650\end{array}$ & $\begin{array}{c}26.800 \pm \\
0.158\end{array}$ \\
\hline T11 ml (2.5 & 1 & 1 & 1 & 1 & 1 \\
$\mathbf{u L / 1 0 0 g})$ & $133.379 \pm$ & $114.160 \pm 1$ & $89.688 \pm 1$ & $34.305 \pm 1$ & $23.638 \pm 1$ \\
CeO & 1.758 & 1.084 & 0.749 & 0.740 & 0.603 \\
\hline T2 ml 3.7 & 1 & 1 & 1 & & \\
$(\mathbf{u L} / \mathbf{1 0 0 g})$ & $135.946 \pm 1$ & $118.717 \pm 1$ & $99.684 \pm 1$ & $40.402 \pm$ & $23.737 \pm 1$ \\
CeO & 0.905 & 0.950 & 1.649 & 1.681 & 0.186 \\
\hline
\end{tabular}

*I different from control $\mathrm{p}<0.05$

Plasma HDL-C concentrations are not an appropriate marker of vascular effects of HDL and therefore do not represent a reliable therapeutic target(13). Recent studies have focused on measuring other indices of HDL, such as the functionality, size, or number of HDL-particle. Of all the indices, two markers associated with HDL functionality, i.e., HDL-LOOH and HDL-TG, are clinically available markers.

A lipid panel including these two markers is expected to serve as an initial screening procedure for predicting approximate risks of cardiovascular disease.(14).

That administration of sodium selenite and a combination of sodium selenite and $\mathrm{CeO}_{2}$ nanoparticles significantly reduced $(P<0.05)$ plasma LDL compared to the diabetic group(15). The nano and metal forms of of $\mathrm{CeO}_{2}$ did not cause significant change. Treatment with $\mathrm{CeO}_{2} \mathrm{NPs}$ was able to reduce the size and content of hepatocyte lipid droplets, the hepatic concentration of triglyceride(16).

\section{Conclusion}

The present study concluded that different doses and periods of intraperitoneal administration of cerium oxide nanoparticle in mice effect negatively blood parameters while elevated lipid profile,

\section{References}

1. Ju-Nam, and J. R. Lead. Manufactured nanoparticles: An overview of their chemistry, interactions and potential environmental implications. The Science of the Total Environment .2008-400 (1-3) 396-414

2. GaiserB. „, Teresa F Fernandes, Mark A Jepson, Jamie R Lead, Charles R Tyler, Mohammed Baalousha, Anamika Biswas, Graham J Britton, Paula A Cole, Blair D Johnston, Yon Ju-Nam, Philipp Rosenkranz, Tessa M Scown, Vicki Stone. Interspecies comparisons on the uptake and toxicity of silver and cerium dioxide nanoparticles.Environ Toxicol Chem.2012) ;31(1):144-54

3. Xia D, et al,. Structural analysis of cytochrome bc1 complexes: implications to the mechanism of function. BiochimBiophysActa .2013)1827(11-12):1278-94.

4. Shaw P.,Sharp W,Jonathan B. Attention-deficit/hyperactivity disorder is characterized by a delay in cortical maturation. National Academy of Sciences.2007- 104(49):1964954 
5. Jessica T. Dahle and Yuji Arai .Environmental Geochemistry of Cerium: Applications and Toxicology of Cerium Oxide Nanoparticles. IJERPH 2015-Volume 12 Issue 2 10.3390

6. Dreher A.(2004)The Influence of IMF Programs on the Re-election of Debtor Governments.Economic and politicsVolume16, Issue1Pages 53-76.

7. Park, J., Park, S., Seryun Kim, S., Jaeyoung C., Ahn, J., Seungmin L., Sunggon K. An informatics pipeline supporting phylogenomic analysis of fungal transcription factors .Bioinformatics,2008- Volume 24, Issue 7, , Pages 1024-1025,

8. Reeda, C Daniel, Christopher K. Algarb, Julie A. Huberb , and Gregory J. Dicka Genecentric approach to integrating .environmental genomics and biogeochemical models .February 4, 2014 . vol. 111 . no. $5: 1879-1884$

9. Adua OA and Akinmuyisitana IW (2013) Growth performance and blood profile of female rabbits fed dietary Cerium Oxide .Journal of Bio-Science.Vol 21.

10. MassodNegahdary, A Asadi, S Mehrtashfar, M Imandar, H Akbari-DastjerdiA biosensor for determination of $\mathrm{H} 2 \mathrm{O} 2$ by use of HRP enzyme and modified CPE with ZnONPsInternational.Journal of Electrochemical Science.2012- 7 (6), 5185-5194

11. Ali Alkaladia,d, Nasr A.M. Nasr El-Deen b , Mohamed Afifia,c,d , Osama A. Abu Zinadah a, (2015) Hematological and biochemical investigations on the effect of vitamin $\mathrm{E}$ and $\mathrm{C}$ on Oreochromisniloticus exposed to zinc oxide nanoparticles Saudi Journal of Biological SciencesVolume 22, Issue 5, Pages 556-563

12. Neda Eskandari, , Sanaz Nikpur,2 Ghazal Ghasrahmad, FarnooshAttar,et al.,(2018)Biophysical, docking, and cellular studies on the effects of cerium oxide nanoparticles on blood components: in vitro. Int J Nanomedicine. 2018; 13: 4575-4589

13. Winfried März, Marcus E. Kleber, Hubert Scharnagl, Timotheus Speer, Stephen Zewinger, Andreas Ritsch, Klaus G. Parhofer, Arnold von Eckardstein, Ulf Landmesser, and Ulrich Laufs (2017)HDL cholesterol:reappraisal of its clinical relevance.Clin Res Cardiol. 2017; 106(9): 663-675.

14. Fumiaki Itoand Tomoyuki Ito.High-Density Lipoprotein (HDL) Triglyceride and Oxidized HDL: New Lipid Biomarkers of Lipoprotein-Related Atherosclerotic Cardiovascular Disease.Antioxidants (Basel).;2020- 9(5): 362.

15. NazilaPourkhalili, Asieh Hosseini, Amir Nili-Ahmadabadi, ShokoufehHassani, Mohsen Pakzad, Maryam Baeeri, AzadehMohammadirad, and Mohammad Abdollahi(2011(Biochemical and cellular evidence of the benefit of a combination of cerium oxide nanoparticles and selenium to diabetic rats. World J Diabetes $15 ; 2(11)$ : 204-210.

16. Silvia Carvajal, MeritxellPerramón, Denise Oró , Eudald Casals , Guillermo FernándezVaro , Gregori Casals , Marina Parra , Bernardino González de la Presa , Jordi Ribera , Óscar Pastor, Manuel Morales-Ruíz, Víctor Puntes, Wladimiro Jiménez (2019)Cerium oxide nanoparticles display antilipogenic effect in rats with non-alcoholic fatty liver disease.Sci Rep. 6;9(1):12848 